\title{
PERAN PENDIDIKAN KEWARGANEGARAAN DALAM PEMBINAAN KARAKTER SIKAP DAN PERILAKU GENERASI MUDA PASCA KONFLIK SOSIAL AMBON
}

\author{
Laros Tuhuteru \\ Dosen FKIP Universitas Pattimura Ambon \\ e-mail: larostuhuteru@yahoo.com
}

\begin{abstract}
Absract
The purpose of this study is to fully understand the character of the younger generation of post social conflict in Ambon city, and the role of local culture and the role of citizenship education in youth character building and democratic values in Ambon. This descriptive study used a qualitative approach with case study methodes, data collection techniques through in-depth interviews, direct observation, documentation studies. Informants were selected purposively and the data were analyzed qualitatively. The result showed that the pattern of character building youth social post-conflict Ambon city based on local cultural values, proved to be able to handle several cases related to the fight between the community and promote the value of fraternal youth to make sound decisions agreed by consensus to reach consensus. Development of socializing together in getting values from multiple approaches including religious values (universal truth), the value of culture and the arts such as working together (gotong royong) and eat patita ngungare jujaro movement, ale flavors beta flavor, bamboo crazy event.
\end{abstract}

Keywords: Role of Civics, Character of Young Generation, Social Conflict 


\begin{abstract}
Abstrak
Tujuan penelitian ini untuk memahami masalah secara lengkap mengenai karakter generasi muda pasca konflik sosial di kota Ambon, dan peran budaya lokal serta Pendidikan Kewarganegaraan dalam pembinaan karakter generasi muda dan nilai-nilai demokrasi di Ambon. Penelitian ini bersifat deskriptif menggunakan pendekatan kualitatif dengan metode studi kasus, teknik pengumpulan data melalui wawancara secara mendalam, obsevasi langsung, dan studi dokumentasi. Informan dipilih secara purposive dan data hasil penelitian dianalisis secara kualitatif. Hasil penelitian menunjukkan bahwa pola pembinaan karakter generasi muda kota Ambon pasca konflik sosial berdasarkan budaya lokal, sehingga dapat menangani beberapa kasus yang berkaitan dengan perkelahian antar masyarakat dan pemuda serta mengedepankan nilai persaudaraan untuk menghasilkan keputusan yang disepakati bersama berdasarkan musyawarah mencapai mufakat. Mengembangkan kebersamaan yang di hasilkan dari beberapa pendekatan diantaranya nilai agama, nilai budaya seperti masohi makan patita gerakan jujaro dan ngungare, ale rasa beta rasa, potong di kuku rasa di daging, dan acara bambu gila.
\end{abstract}

Kata Kunci: Peran PKn, Karakter Generasi Muda, Konflik Sosial. 


\section{A. Pendahuluan}

Konflik sosial Ambon dapat memberikan potensi positif terhadap sikap dan perilaku serta perubahan cara pandang dan berpikir bagi generasi muda dan masyarakat Ambon, khususnya masyarakat dan generasi muda pribumi yang sebelum konflik sosial perasaan gengsinya terhadap pekerjaan, jika pekerjaan itu menurutnya hina seperti menjadi tukang pikul bakul, tukan becak, atau berdagang di pasar. Selain itu sikap dan perilaku generasi muda Ambon pasca konflik sosial sering mabukmabukan, kurang rasa menghargai orang lain. Namun pasca konflik sosial, perasaan gengsi sudah tidak ada dalam benak masyarakat dan generasi muda Ambon mereka lebih berpikir maju dan tidak mau ketinggalan dengan orang pendatang dari luar Ambon.

Untuk membina karakter sikap generasi muda di atas, sanggat membutuhkan suatu pendidikan seperti Pendidikan Kewarganegaraan (PKn) sebagai sebuah program pendidikan di sekolah perlu menciptakan iklim yang kondusif untuk mendukung proses belajar dan mendidik warga negara muda (siswa) melalui proses belajar kondusif dan demokratis. Untuk menciptakan lingkungan yang damai dan menyenangkan agar terjadinya proses belajar yang lebih baik. Sebaliknya jika konflik dan kekerasan dalam kehidupan di sekolah maupun masyarakat memberikan dampak negatif terhadap proses belajar siswa.

Pembelajaran PKn sangat diperlukan dan memiliki nilai serta kedudukan yang sangat strategis bagi 'national character building' dalam arti seluas-luasnya terutama dalam membentuk warga negara yang baik. Meskipun demikian, dalam pelaksanaanya, PKn sangat rentan terhadap bias politik praktis penguasa (the ruling class) sehingga ia cenderung lebih merupakan instrumen penguasa dari pada sebagai wahana pembangunan watak anak bangsa berdasarkan konstitusi seperti yang dibuktikan oleh sejumlah hasil penelitian para ahli Civic Education seperti dikemukakan Cogan (1998: 5). 
Untuk Dalam rangka mewujudkan sikap dan perilaku generasi muda tersebut maka dapat diperlukan pembangunan pendidikan karakter kebangsaan bagi generasi muda khususnya di Ambon. Dengan demikian dapat merujuk pada 56 (lima puluh enam) sifat-sifat Budi Pekerti Luhur (Edi Sedyawati dkk, 1999), yaitu sebagai berikut : 'bekerja keras, berani memikul resiko, berdisiplin, beriman, berhati lembut, berinisiatif, berpikir matang, berpikir jauh ke depan, bersahaja, bersemangat, bersikap konstruktif, bersyukur, bertanggung jawab, bertenggang rasa, bijaksana, cerdik, cermat, dinamis, efisien, gigih, hemat, jujur, berkemauan keras, kreatif, kukuh hati, lugas, mandiri, mawas diri, menghargai karya orang lain, menghargai kesehatan, menghargai waktu, pemaaf, pemurah, pengabdian, pengendalian diri, produktif, rajin, ramah tamah, rasa kasih sayang, rasa percaya diri, rela berkorban, rendah hati, sabar, setia, sikap adil, sikap hormat, sikap tertib, sopan santun, sportif, susila, tangguh, tegas, tekun, tepat janji, terbuka, dan ulet'.

\section{B. Metode}

Penelitian ini dimaksudkan untuk memahami perilaku manusia dari kerangka acuan dari si pelaku itu sendiri, yakni bagaimana si pelaku memandang dan menafsirkan kegiatan dari segi mereka yang biasa disebut dengan presfektik emik. Dalam hal ini, peneliti berusaha memahami dan menggambarkan apa yang dipahami dan digambarkan oleh subyek penelitian. Untuk maksud tersebut, peneliti menggunakan pendekatan kualitatif. Penelitian dengan menggunakan pendekatan kualitatif ini berupaya memusatkan perhatian studinya pada realita sebagai produk pikir manusia dengan segala bentuk subyektivitas, emosi dan nilai-nilai yang dianutnya.

Sesuai dengan masalah yang diteliti, pendekatan yang digunakan dalam penelitian ini adalah pendekatan penelitian kualitatif, pendekatan yang tidak menggunakan upaya kuantitatif untuk perhitunganperhitungan statistik, melainkan lebih menekankan pada kajian interpretatif. Hal ini sesuai dengan pendekatan Vernon van Dyke (Saprya, 2007: 130) bahwa pada 
prinsipnya pendekatan kualitatif yang digunakan dalam penelitian ini berimplikasi pada penggunaan ukuran-ukuran kualitatif secara konsisten, artinya dalam pengolahan data, sejak mereduksi, menyajikan dan memperivikasi dan menyimpulkan data tidak menggunakan upaya kuantifikasi perhitungan-perhitungan secara statistik, seperti lazimnya dalam penelitian kuantitatif akan tetapi lebih menekankan pada kajian interpretatif.

Dipilihnya metode studi kasus dalam penelitian ini adalah karena konflik sosial antarwarga, antar umat beragama, dan antar anak muda sering terjadi dengan setting yang berbeda-beda. Konflik sosial di Indonesia merupakan fenomena yang partikular- karakteristik dan memerlukan penjelasan yang lebih mendalam dan spesifik. Meski penelitian kasus biasanya mencari sesuatu yang umum dan khusus dari sebuah kasus, namun hasil karyanya hampir selalu menyajikan sesuatu yang unik dan spesifik (Stoufer dan Stake dalam Zaenuri, 2012: 23).
Sementara istilah studi kasus itu sendiri adalah sebagai salah satu metode dalam penelitian kualitatif. Istilah studi kasus merupakan gabungan antara studi dan kasus. Kata studi berasal dari bahasa inggris, study, yang sudah dibakukan dalam bahasa Indonesia berarti pelajaran, lokarya, atau penyidikan (Echols \& Shadly, dalam Erawati 2011: 113). Sedangkan istilah kasus menurut Hasan dalam Erawati (2011) adalah suatu peristiwa, kejadian, fenomena atau situasi tertentu yang terjadi di tempat tertentu dan berhubungan dengan aspek-aspek kehidupan manusia di masa lalu, masa kini, atau masa yang akan datang. Istilah studi kasus yang dimaksud adalah sebuah metode penelitian dalam penelitian kualitatif. Pengumpulan data dalam penelitian ini dilakukan dengan berbagai cara dan teknik yang berasal dari berbagai sumber baik manusia maupun bukan manusia. Dalam penelitian ini, teknik pengumpulan data dan informasi yang digunakan adalah teknik pengumpulan data kualitatif, yang meliputi observasi, studi wawancara 
mendalam, dan studi dokumentasi. Pengambilan data dilakukan dengan metode snowball sampling dengan proses jumlah kecil informan kemudian melibatkan pihak yang terkait dengan informan awal untuk dijadikan informan dan seterusnya sehingga menjadi besar seperti bola salju (snowball). Untuk menggali informasi dari sumber data yang dipilih digunakan sejumlah teknik pengumpulan data kualitatif, yaitu observasi, wawancara mendalam, dan studi dokumentasi.

Analisis data menurut Bogdan dan Biklen (1982: 145) adalah proses pencarian dan penyusunan secara sistematis terhadap transkrip wawancara, catatan lapangan, dan bahan-bahan lain yang terkumpul untuk meningkatkan pemahaman tentang data serta menyajikan apa yang telah ditemukan kepada orang lain. dalam penelitian kualitatif-induktif, analisis data dilakukan dengan mencari korelasi antara satu fakta dengan yang lain untuk menemukan pengertian dan makna yang lebih tepat karena pada dasarnya faktafakta itu cenderung berserak dan fragmentaris. Identifikasi bagianbagian, memahami relasi antara bagian, memahami hubungan bagian dengan keseluruhan, dan mengungkapkannya merupakan kegiatan yang paling penting dalam analisis ini, termasuk di dalamnya melakukan interprestasi dan pemaknaan.

\section{Pembahasan Dan Hasil}

Kondisi karakter generasi muda pasca konflik sosial yang terjadi di Ambon berdasarkan temuan lapangan bahwa: situasi pasca konflik berpengaruh terhadap sikap dan perilaku generasi muda akibat kerusuhan yang melanda kehidupan masyarakat kota Ambon beberapa tahun yang lalu sejak 1999, sehingga ada kelompok masyarakat tertentu dan sekolah khususnya pendidikan Kewarganegaraan yang terus melakukan pembinaan terhadap sikap dan perilaku generasi muda kota Ambon agar karakter generasi muda Ambon sesuai dengan nilainilai luhur budaya masyarakat di Ambon. Karena kondisi karakter generasi muda kota Ambon saat ini sanggat jahu dari harapan maka 
keinginan keluarga, sekolah, dan tokoh masyarakat agar sikap dan perilaku generasi muda pasca konflik sosial kota Ambon dapat mengikuti perkembangan dan perubahan zaman dan generasi muda bisa menerima keperbedaan baik agama, etnis suku, dan budaya di Ambon. Selain itu pembinaan sikap dan perlaku generasi muda lebih diarahkan kepada tujuan perubahan sosial berjangka panjang yang lebih menekankan rekonstruksi struktur damai dalam masyarakat. Kondisi karakter generasi muda pasca konflik mengara kepada suatu keadaan dinamis, partisipatif, dan berjangkapanjang, yang berdasar pada nilainilai sosial yaitu: rasa kekeluargaan, kejujuran, kebersamaan serta rasa damai di keluarga, sekolah, dan komunitas lingkungan masyarakat kota Ambon.

Akibat situasi konflik dapat berpengaruh terhadap sikap dan perilaku karakter generasi muda sampai pada pasca konflik pun masih ada bekas yang tertanam dalam jiwa generasi muda di Ambon diantaranya adalah:

\section{MerosotnyaTingkat Pendidikan}

Dikalangan generasi muda justru rumah dan gedung-gedung sekolah ikut hancur, anak-anak muda pun putus harapan untuk tidak mau ikut pendidikan saat pasca konflik terjadi, mereka kemudian tinggal sampai saat ini di berbagai tempat pengungsian, sehingga terasa betul betapa menderitanya hidup sebagai pengungsi. Selain itu anak-anak usia sekolah tidak sempat mengikuti pendidikan atau sekolah dengan baik akibat kekhawatiran sewaktu-waktu muncul kekacawan yang berakibat konflik yang lebih besar seperti konflik yang terjadi tahun 1999.

Dengan demikian kondisi seperti itu dapat menganggu sikap dan perilaku generasi muda yang dapat menganggu penyelengaraan publik ruang gerak generasi muda jadi sempit akibat tingkat pendidikan generasi muda semakin merosot terutama menyangkut sikap karakter generasi muda pasca konflik. Kesulitan-kesulitan di sekolah, seperti nilai yang menurun, dan kesulitan konsentrasi, anak menjadi pessimis, tidak ada harapan masa depan, kehilangan keinginan untuk survive, bermain, menikmati hidup. 
Minum obat narkotik atau ikut gerakan-gerakan yang melawan hukum dan kebudayaan.

\section{Muncul Rasa Trauma bagi Generasi Muda}

Akibat konflik sosial 1999, maka dengan demikian kondisi pasca konflik di Ambon dapat berpengaruh yakni; munculnya rasa trauma bagi anak-anak muda seperti: anak-anak ketika mereka diajak menggambar, justru mereka menggambar senjata, apa yang mereka lihat waktu kejadian kerusuhan pada beberapa tahun yang lalu, sampai saat ini trauma-trauma generasi muda masih melekat dalam pikiran mereka ini kalau tidak ada yang melakukan rekonstruksi pemikiran mereka lagi mungkin beberapa tahun ke depan tetap mereka akan angkat senjata dan berpikir hanya untuk perang.

Selain itu anak-anak muda di Ambon pasca konflik mereka merasa tidak ada kepercayaan diri sendiri karena hidup lingkungannya, maupun struktur-struktur sosial dan aturan-aturan hidupnya hancur kejadian traumatis ini mengakibatkan kebingungan, kelukaan jiwa, dan kelainan dalam tabiat anak. Menjadi waspada terus-selalu melihat-lihat sekeliling karena takut ada bahaya. Berlaku seperti tidak takut karena sesuatu dan kepada siapapun juga. Kalau ada kerusuhan mereka berlaku tidak wajar, sambil berkata mereka tidak takut pada apapun juga, sambil berkata-kata mau membalas dendam. Anak-anak muda juga trauma jika mendengar letusan senjata, sirene mobil militer, dan suara tangis seorang ibu yang kehilangan anaknya dan seorang anak yang kehilangan semuanya. Ketakutan seperti itu ketika konflik redah maka suara-suara seperti itu masih ada di ingatan mereka sehingga ada bunyi mercon atau petasan bahkan bunyi suara orang berjualan di pasarpun muda kaget/terkejut dan ketakutan bagi anak-anak muda di Ambon.

\section{Sikap Main Hakim Sendiri yang Dilakukan Generasi Muda.}

Akibat konflik sejak 1999 dapat mempengaruhi para generasi muda untuk menunjukan sikap dan perilaku main hakim sendiri yang dapat ditimbulkan dari luar diri anak muda misalnya penganiayaan, perampasan, dan perkelahaian kasus- 
kasus ini sering ditemukan di kalangan generasi muda yang melanggar hukum (berkonflik dengan hukum). Selain itu pelanggaran hukum yang dilakukan anak-anak muda diantaranya pencurian, penggunaan narkoba, perjudian, dan mabuk-mabukan. Ketika pasca konflik sosial generasi muda juga temparemennya tinggi, tidak peduli dengan tanggung jawab, sering bikin aksi yang meresahkan banyak orang.

Dalam kehidupan sehari hari di Ambon pasca konflik sosial, kasus pelangaran hukum oleh generasi muda terutama yang berkaitan dengan sikap atau perbuatan main hakim sendiri, seperti pertikaian antar kelompok (konflik sosial), pengeroyokan, terhadap orang yang dituduh atau ketangkap basah melakukan pencurian. Sikap pengeroyokan sebagai bentuk main hakim sendiri dalam menyelesaikan pertikaian atau konflik juga tampak sangat kuat di kalangan para pelajar atau generasi muda. Hal ini menurut data kriminalitas di tingkat kota cenderung mengindikasikan peningkatan sikap generasi muda seperti ini tentu sangat memprihatinkan, karena sikap semacam itu mencerminkan suatu kehidupan yang tidak bermoral yang semestinya dalam menyelesaikan konflik dikalangan generasi muda dengan cara-cara yang demokrasi atau penyelesaian melalui jalur hukum.

\section{Sikap Kurang Menghargai Orang Lain}

Ketika pasca konflik sosial beberapa pihak khawatir termasuk masyarakat, keluarga dan lembagalembaga sekolah, akan situasi pasca konflik berdampak kepada sikap dan perilaku generasi muda yang kurang menghargai orang lain seperti, rengangnya rasa persahabatan, jarang menerima adanya perbedaan, kurang menghargai sifat-sifat yang dimiliki orang lain, berbicara tidak jujur, kurang ramah. Hal demikian terjadi karena selama konflik sosial para generasi muda selalu berada dalam situasi perang/konflik.

\section{Sifat Kekerasan Bagi Generasi Muda \\ Lebih lanjut dapat dikatakan Peneliti bahwa; Dampak dari konflik}


sosial yang berkecamuk di Ambon sejak tahun 1999 menimbulkan banyak masalah baru. Salah satunya adalah timbulnya sifat kekerasan pada generasi muda dalam kesehariannya sering membrontak ketika menghadapai suatu masalah, dan masalah tersebut tidak diselesaikan dengan cara-cara yang demokratis atau melalui cara musyawara akan tetapi lebih banyak menyelesaikan masalah dengan pendekatan kekerasan. Hal demikian dapat menimbulkan kasus-kasus kekerasan seperti terjadi perkelahian antar-warga. Khususnya kalangan muda di satu kelurahan, Desa, atau Gang-gang tertentu.

Dilihat dari lima masalah sikap dan perilaku generasi muda di atas, maka dapat dikatakan bahwa kondisi karakter generasi muda pasca konflik sosial Ambon perlu diarahkan pada pembinaan terhadap sikap dan perilaku generasi muda jika tidak dilakukan, maka karakter anak-anak muda kita pasca konflik sosial pasti dapat mengarah pada sikap kekerasan, mengeluar kata-kata yang kurang terpuji dan tidak sesuai dengan nilai-nilai budaya lokal di
Ambon. Ambon yang selama ini dibanggakan sebagai daerah yang sangat toleran dengan kehidupan beragamanya, bahkan selalu dipromosikan oleh para elite bangsa sebagai teladan atau contoh bagi kehidupan antara agama baik di Indonesia maupun didunia, kini benar-benar rapuh dan hancur akibat konflik sosial 1999.

Upaya membangun kembali sikap dan perilaku generasi muda serta semangat kekeluargaan telah diupayakan pemerintah daerah, tokoh masyarakat, tokoh adat, tokoh pemuda, termasuk pemerintah kelurahan, dengan cara mengembalikan salah satu budaya lokal yang dikenal dengan Masohi, atau gotong royong, pela gandong, (kerukunan), makan patita (kebersamaan) ale rasa beta rasa potong dikukuh rasa didaging (keadilan) untuk menggalang kebersamaan. Kegiatan Masohi ini dilakukan melalui satu kegiatan bersama. Dalam kegiatan tersebut semua masyarakat dan generasi muda kota Ambon didorong ikut terlibat tanpa membedakan suku, agama, ras, dan golongan. Misalnya, 
dalam pembangunan Gereja generasi muda Muslim turut menyumbang. Sebaliknya, apabila kaum Muslim membangun Masjid, generasi muda dan masyarakat Nasrani turut menyumbang. Kebiasaan lainnya yang sering ditumbuhkan di masyarakat kota Ambon adalah makan bersama (makan pattita) sebagai simbol kebersamaan dan persaudaraan baik Islam maupun Kristen. Semua kegiatan ini biasanya diikuti oleh generasi muda pemerintah kota, tokoh-tokoh masyarakat, dan masyarakat umum.

\section{E. Simpulan}

Berdasarkan sejumlah
temuan penelitian yang telah
$\begin{aligned} & \text { diuraikan di atas tampak bahwa } \\ & \text { Pendidikan }\end{aligned}$ Kewarganegaraan
berperan penting dalam
pembentukan karakter generasi muda
pacsa konflik sosial di Ambon. Hal
tersebut dikarenakan: a) PKn yang
dilaksanakan dipersekolahan tidak
hanya menitipberatkan pada
penguasaan meteri pembelajaran
secara kognitif saja, tetapi meliputi
pula pada pembentukan sikap
karakter selaku generasi muda
terutama siswa. Dengan kata lain,

paradigma pembelajaran PKn sudah mulai berubah dari education abaout democracy ke arah education for democracy; b) Pembelajaran PKn sudah dilakukan dengan menggunakan metode pembelajaran yang tidak bersifat persekolahan saja akan tetapi PKn bisa dilakukan antara masyarakat organisasi sosial politik, organisasi kepemudaan dan keluarga, sehingga PKn lebih teredorong penguatan peran dan kedudukannya sebagai pendidikan karakter dan kesadaran berdemokrasi bagi generasi muda terutama siswa; dan c) Materi pembelajaran PKn pada dasarnya mengikuti prinsip dimana kurikulum diletakan.

Karena latar belakang situasi pasca konflik yang dapat menciptakan efek-efek sosial yang buruk, serta terjadinya dekadensi moral, meningkatnya ketidak jujuran siswa dan kurangnya rasa hormat terhadap orang tua dan guru. Dengan demikian harapan masyarakat agar pembinaan karakter generasi muda pasca konflik melalui pemebelajaran PKn yang mampu mengerakan siswa untuk tahu tentang hak dan kewajiban sebagai warga negara, dan 
mengajarkan kepada siswa atau generasi muda yang berjiwa demokrasi serta melupakan peritiwaperistiwa yang tidak bermoral di lingkungan masyarakat maupun di sekolah sehingga para generasi muda bisa hidup berdampingan dengan sesama masyarakat di Ambon.

\section{Daftar Pustaka}

Bogdan, dan Biklen, S, K. (1982). Qualitative Research for education An Introduction to theory and Methods. Boston : Allyn and Bacon.

Budimansya, Dasim dan Suryadi, Karim. (2008). PKN dan Msyarakat Multikultural, Bandung: Program Studi Pendidikan

Kewarganegaraan Universitas Pendidikan Indonesia.

Cogan, Jhon J, (1998). Developing The Civil Sicyety: The Role Of Civic Education. (paper). Presented In The Confrance On Civic Education For Civil Society, Organized by Cived In Colaboration With Visis. Bandung : Hotella Papandaya, Maret 16-17, 1999

Cogan, Jhon J. dan Derricot, R. (1998). Citizenship for the 21 Century: An International Perspeltive an Education.London:

Cogan Page.

Edi, S dkk. (1999). Pedoman Penanaman Budi Pekerti Luhur. Jakarta: Bali Pustaka.

Erawati. D. (2011) Pengembangan Model Sosialsiasi Nilai Kebersamaan sebagai Upaya Menanggulangi Konflik Antar Umat Beragama dalam kehidupan Bermasyarakat. (studi Kasus di Forum Kerukunan Umat Beragama Kota Palangka Raya), Disertasi Doktor Pada Universitas Pendidikan Indonesia.

Miles dan Huberman. (1992). Analisis Data Kualitatif. UPI- Press : Jakarta.

Lincoln, Y.S. \& Guba, E.G. (1985). Naturalistic Inquiry. Baverly Hills: Sage Publication.

Salim, A. (2001). Teori dan Paradigma Penelitian Sosial dari Denzim Guba dan Penerapannya, Yogyakarta: Tiara Wacana.

Sapriya H. (2007). Pemikiran Pakar Tentang Pendidikan Kewarganegaraan Dalam Pembangunan Karakter Bangsa, Disertasi Doktor Pada Universitas Pendidikan Indonesia.

Winataputra Udin dan Budimansyah Dasim (2007). Civic 
Education, Konteks dan Landasan Bahan Ajar dan Kultur kelas, Bandung Sekolah Pasca Sarjana Universitas Pendidikan Indonesia.

Zaenuri, Achmad, (2012), Analisis Resolusi Konflik Antara Umat Beragama dalam Prespektif Pendidikan Kewarganegaraan Berbasis Masyarakat, Disertasi Doktor: Tidak Diterbitkan. 